Volume 13 Number 1, January-March 2019: pp. 75-86. Copyright (c) 2019 FIAT JUSTISIA. Faculty of Law, Lampung University, Bandarlampung, Lampung, Indonesia. ISSN: 1978-5186 | e-ISSN: 2477-6238.

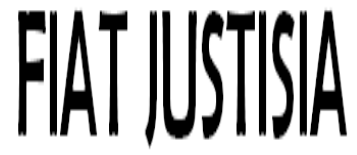

Fiat Justisia is licensed under a Creative Commons Attribution 4.0 International License, which permits unrestricted use, distribution, and reproduction in any medium, provided the original work is properly cited.

\title{
The Modus Operandi of Children as the Offender in Committing Human (A study in Kepolisian Resor Kota Besar Surabaya)
}

\author{
Chintya Dewi Restyana S \\ Magister Ilmu Hukum Universitas Airlangga, Indonesia \\ chintyadewirest@gmail.com
}

\begin{abstract}
Children who are supposed to be protected by the state, law, and society can be an organised criminal offender such as human trafficking. In Surabaya, there were 32 human trafficking cases since 2011-2018 that was handled by Polrestabes (Capital City Police) Surabaya where the offenders were children. The problem in this research is the Modus Operandi of children as the offender in the act of human trafficking. This research used empirical research method with socio-legal and criminological approach. From the research result, the author found out that children that committed human trafficking were caused by the influence of economic factor, environment, and lifestyle. From those causes, the modus operandi of the children as the offender in committing human trafficking was by getting acquainted in social media like Facebook and Whatsapp and then make an offer to the potential buyer. The National Police has two ways in preventing and tackling children as the offenders of human trafficking which are by prevention and repressive effort Children
\end{abstract}

Keyword: Children, Human trafficking, Modus Operandi

How to Cite: Chintya Dewi Restyana S, "The Modus Operandi of Children as the Offender in Committing Human (A study in Kepolisian Resor Kota Besar Surabaya)", Fiat Justisia, 13 (1), (2019).

DOI: https://doi.org/10.25041/fiatjustisia.v13no1.1508 


\section{A. Introduction}

In its early development, human trafficking was not a form of criminal. Consequently, no punishment could be given to the offenders. At the time of independence, human trafficking was finally stated as an act that is against the law. ${ }^{1}$ Human trafficking becomes the highlight in society because it involves children as victims and also as the offender. Human trafficking has been settled in law_number 21 of 2007 on the Eradication of Human Trafficking (furthermore will be stated as Human Trafficking Law). The article 1 paragraph (3) of the Law stated that act of crime in human trafficking should mean "any crime or series of crimes which meet the qualifications set out in this Law."

According to Wirjono Prodjodikoro, crime is an act that can cause the perpetrator to be sentenced. ${ }^{2}$ The increasing of the act of crime also cause the increasing of the offender, whether among adults or children. Children are the successor of state and still incapable of controlling their emotion; therefore it can be stated that children are unable to determine whether or not their actions are right. Children as the offender of crime must be protected; as it is regulated in Law Number 23 of 2002 on Child Protection. On Child Protection Law, the Article 4 stated that "every child is entitled to live, grow, develop, and participate decently in line with the dignity of humanity, and acquire protection from violence and discrimination." It is also in line with human rights as stated in the Article 52 paragraph (1) and (2) of Law Number 39 of 1999 on Human Rights (furthermore will be stated as Human Rights Law) which; (1) "every child has the right to protection by parents, family, society, and state"; (2) "children's rights are human rights which in the children interest are recognized and protected before the law at the time of conception". The first paragraph explains any child must be protected and not to be treated in an infeasible way. The second paragraph explains the recognition and protection of children before the law. Under the laws that are already mentioned before, it is clear that children as the offender of human rights trafficking must be protected.

Children can commit crime because of many factors such as child delinquency/juvenile delinquency. ${ }^{3}$ The term 'delinquent' comes from

\footnotetext{
${ }^{1}$ Hotlarisda Girsang, "Pemberantasan Tindak Pidana Perdagangan Orang Melalui UndangUndang Pencegahan dan Pemberantasan Tindak Pidana Pencucian Uang," Jurnal Ilmu Hukum, Maret, (2004), p. 3.

${ }^{2}$ Masruchin, Rubai, Asas-Asas Hukum Pidana, Malang: UM PRESS dengan Fakultas Hukum Universitas Brawijaya, (2001), p. 22.

${ }^{3}$ The common used terminology in various English speaking states is juvenile delinquency. However, since the Indonesian term has no differentiation in using the word "anak" whether speaking about "anak" in general or "anak yang berhadapan dengan hukum", it will be suitable for this journal to only use "child" terminology. Using both "juvenile" and "child" in this journal may cause confusion.
} 
delinquency which can be defined as child or adolecent delinquency. ${ }^{4}$ "According to Anthony M.Platt ${ }^{5}$, the definition of delinquency is a child's activities which includes (1) criminal act if an adult commits it, (2) a violation act of state and society's regulation, (3) a vicious immoral behaviors, truancies, profanity and impolite expressions, growing up on the streets and associating with bad people are possible to influence bad behaviour for children in the future." A criminal act committed by children from 2011 to 2018 is shown in the data which was acquired from Polrestabes Surabaya described in the table below:

Table 1.1

Crimes that are Committed by Children from 2011-2018

\begin{tabular}{|c|l|c|c|c|c|c|c|}
\hline No. & Types of Crime & \multicolumn{5}{|c|}{ Year } & Total \\
\cline { 3 - 7 } & & $\begin{array}{c}\mathbf{2 0 1 1 -} \\
\mathbf{2 0 1 4}\end{array}$ & $\mathbf{2 0 1 5}$ & $\mathbf{2 0 1 6}$ & $\mathbf{2 0 1 7}$ & $\mathbf{2 0 1 8}$ & \\
\hline 1. & Theft & 5 & 3 & 2 & - & 2 & 12 \\
\hline 2. & $\begin{array}{l}\text { Aggravated } \\
\text { Theft }\end{array}$ & 19 & 4 & 3 & 4 & 3 & 33 \\
\hline 3. & $\begin{array}{l}\text { Motor Vehicle } \\
\text { Theft }\end{array}$ & 4 & - & 1 & 1 & 1 & 7 \\
\hline 4. & Robbery & 13 & 1 & 1 & 2 & 1 & 18 \\
\hline 5. & Fraud & 2 & - & - & - & - & 2 \\
\hline 6. & Fencing & 1 & - & - & 1 & - & 2 \\
\hline 7. & $\begin{array}{l}\text { Human } \\
\text { Trafficking }\end{array}$ & 7 & 5 & 6 & 10 & 4 & 32 \\
\hline 8. & Joint Battery & 5 & 1 & 1 & - & - & 7 \\
\hline 9. & Gambling & 1 & - & - & - & - & 1 \\
\hline 10. & Child Protection & 5 & 4 & 1 & - & 2 & 12 \\
\hline 11. & $\begin{array}{l}\text { Possession of } \\
\text { 12. }\end{array}$ & 3 & 1 & 2 & - & - & 6 \\
\hline Sharp Weapon & Homicide & 1 & - & - & - & - & 1 \\
\hline 14. & Child Abduction & 2 & - & - & 1 & 1 & 4 \\
\hline TOT AL & 1 & - & 1 & - & - & 2 \\
\hline
\end{tabular}

Data Source: Secondary data processed on March 2019

4 Marlina, Peradilan Pidana Anak di Indonesia Pengembangan Konsep Diversi dan Restroative Justice, Medan : Refika Aditama, (2009), p. 37.

${ }^{5}$ Ibid., p. 38. 
From the table above, it is shown that human trafficking is the second most committed crime by children. An example case was committed in Pacific Hotel on Perak Timur Street in Surabaya, where police secured $\mathrm{JN}$, a child under 18 years old, trafficking UKW, 16 years old girl and SA, 23 years old woman to a man. To the investigator, JN admitted that he offered his friend with a price of Rp 1.000.000,- (one million rupiahs) on each person and in every action, he earned a commission of Rp 500.000,(five hundred thousand) from the set price. ${ }^{6}$ From the mentioned case and data, children who commit human trafficking was caused by the desire to benefit themselves by exploiting other children sexually. Child trafficking is a problem that needs to be handled immediately not only on the surface, but it must be eradicated to its root. ${ }^{7}$

Surabaya is a metropolitan city which makes the economy development gradually increases from time to time. The increasing of economic development also gives impact to the number of crime in Surabaya. The case and data that were mentioned before proved that there are still many children as the offender oh human trafficking; and by that, it also proves that Surabaya is a crime-prone city. Aside from the Indonesian Criminal Code (KUHP), human trafficking is regulated under several other regulations, i.e. ${ }^{8}$

- Law Number 21 of 2007 on Human Trafficking from Article 2 to 27.

- Law Number 23 of 2002 on Child Protection Article 68 paragraph (2),

Article 78, Article 84, and Article 85.

Based on those issues above, the author formulated a problem statement; modus operandi of children as an offender in committing human trafficking particularly in Surabaya and the effort in eradicating and preventing children from committing human trafficking.

\section{B. Research Methodology}

This research used empirical research method with a socio-legal approach; an approach method which reviews the principles and the systematics of law, as well as on the identification and effectiveness of law in the society. ${ }^{9}$ Aside from socio-legal method, this research also used criminology approach that is to review the cause of crime which used to find

\footnotetext{
6 Detik.com, "Dua Gadis Belia Dijual Teman Sendiri Seharga Rp 1 Juta (online)" http://news.detik.com/surabaya/read, accessed on 16 December, 2018.

${ }^{7}$ Afan Alfian, "Upaya Perlindungan Hukum Terhadap Tindak Pidana Perdagangan Orang", Fiat Justisia Jurnal Imu Hukum, Vol. 9 No.3, 2017, p.5.

${ }^{8}$ I Gst. Ayu Stefani Ratna Maharani \& Ida Bagus Putra Atmadja, "Sanksi Pidana Terhadap Tindak Pidana Perdagangan Orang (human Trafficking) Di Indoesia”, Jurnal Hukum Universitas Udayana, Vol. 04, No. 03, 2015, p.3.

9 Bambang Sunggono, Metodologi Penelitian Hukum, Jakarta : Raja Grafindo Persada, (2005), p.42.
} 
facts and data to understand the modus operandi of children as the offender of human trafficking and the effort of police especially in the Child and Women Protection Unit in handling the children as the offender of human trafficking in Polrestabes Surabaya. To review the effectiveness of law with the socio-legal method, the research was conducted at Polrestabes Surabaya. The type of data that is used in this research is primary and secondary data. The primary data in this research is the data that directly obtained from the field while secondary data is in the form of literature that affirms the primary data. To collect the data, the author used data collecting technique through profound interviews with the parties that are directly involved in human traffickings, such as police as investigator and community guide. The data analysis method that is used in this research is descriptive-analytical; to explain the obtained data and literature studies and then being analysed with relevant theories. ${ }^{10}$

\section{Discussion}

\section{Modus Operandi of Children as the Offender of Trafficking in Surabaya}

Trafficking is a well-organised crime and difficult to be discovered by many elements, including the police. That's what makes human trafficking difficult to be revealed. An act can be categorised as human trafficking if the purpose of exploiting other people is fulfilled, whether with or without consent, as regulated on Article 2 paragraph (1) of Human Trafficking Law. Exploitation is an act that can be committed with or without the victim's consent, not limited to prostitution, forced service or labor, slavery or any act similar to slavery, oppression, blackmailing, physical use; sexual, reproductive organs, or illegally move or transplant any organ and/or any body tissue or use someone's energy or ability by others to gain profit whether in a form of material or immaterial, as mentioned in the Article 1 point 7 of Human Trafficking Law.

There is a various cause on why children committed human traffickings, such as economic needs or lifestyle. According to Bunga, (fake name) "I committed human trafficking because I need money for the school's needs at that time. I studied beauty major; I need to buy makeup tools. I only have a few money from my pocket money. I'm afraid to ask my parents because they would get angry if I always ask for money." $"$ According to chaos theory, the factors that cause someone commits a crime is the influence of small changes (economy condition, physical condition, social condition,

\footnotetext{
${ }^{10}$ Burhan Ashshofa, Metode Penelitian Hukum, Jakarta: Rineka Cipta, (2002), p.91.

${ }^{11}$ Interview with "Anak Berkonflik Dengan Hukum (ABH), Bunga (not the real name)", on 4 May 2015.
} 
trust, et cetera) which happens in the offender's surrounding. Those little changes gradually affect the offender's behaviour. ${ }^{12}$ The clause about the cause of crime is included in the theories of criminology to know the cause of crime. Criminology is interdisciplinary, which means it is a science that can't stand alone; it is a study result of other science towards crime. ${ }^{13}$ There are several theories concerning the cause of crime, i.e.:

a. Cultural Deviance Theory

Cultural deviance theory view crime as a set of values on the lower class, which shows behaviours in the slump area that cause clashes with the law in the society. Cultural conflict theory is a theory describes where several groups have regulations that regulate behaviour (conduct norms) that is different from the conventional regulations of middleclass people. ${ }^{14}$

b. Social Control Theory

This theory focuses on the techniques and strategies that manage the behaviour of human and bring them to adapt or obey the regulations in society, by viewing on why several people obey the norms. Crime can happen when the powers that control society are weak. ${ }^{15}$ The crime that is committed by children happen because of delinquency.

c. Anomie Theory

Durkheim founded this theory. It explained deviance behaviour that is caused by the economic condition of society. ${ }^{16}$

d. Environmental School Theory

According to the Environmental School Theory, there are several factors of the environment that can cause crime, i.e..$^{17}$

1) An environment that gives the chance of crime to appear

2) The environment of association that gives an example/role model

3) Economic environment

4) Various association environment.

From the cause of children in committing human trafficking, children carry out Modus Operandi to execute their job so that their conduct wouldn't be known by family, their peer, as well as the police. The Modus Operandi in committing human trafficking, i.e.:

\footnotetext{
${ }^{12}$ Agung Fernando Satrya, "Analisis Kriminologis Tentang Anak Pelaku Pencurian Dengan Kekerasan Yang Menggunakan Senjata Tajam”, Jurnal Poenale, Vol. 5 No. 6, (2017), p 9.

${ }^{13}$ Teguh Prasetyo, Kriminalisai Dalam Hukum Pidana, Bandung: Nusa Media, (2011), p.14.

${ }^{14}$ Topo Santoso dan Eva Achjani Zulfa, Kriminologi, Jakarta: Raja Grafindo Persada, (2001), pp.67-68.

${ }^{15}$ Ibid., p. 88.

${ }^{16}$ Romli Atmasasmita, Teori Dan Kapita Selekta Kriminologi, Bandung: Refika Aditama, (1992), p. 35.

${ }^{17}$ Soedjono D, Penanggulangan Kejahatan, Bandung: Alumni, (1983), p.29.
} 


\section{a. Inviting a Friend}

From the interview with a child as the offender of human trafficking, the offender's modus is done by asking for her friend to serve her client. The offender does this modus by offering a huge amount of money and facilities that can the victim get if the victim would follow what the offender wants. The facilities that the victim can get are; being picked up by a car, a recent release cell-phone, and having a huge amount of income on her own in such young age so that she could help her parents or fulfil her desires. ${ }^{18}$ Inviting a friend as a modus can be correlated by the environment school theory of criminology because this modus can happen as the environment gives the chance of that crime to appear as well as the association that gives an example of such behaviour.

\section{b. Voluntarily}

The other modus operandi of the children as the offender of human trafficking is, they voluntarily want to be involved. This modus is commonly used by the children that were once a victim of human trafficking. I Maculata Sherly M. explained that the children that are selling their friends are the ones that have understood the world of human trafficking well and has constantly commit prostitution as they sell themselves to "om". ${ }^{19}$ The explanation is strengthened by the data from child investigator that explained if the children's background is already bad, the children who voluntarily being involved with human trafficking must be already understood that world. ${ }^{20}$ The theory that is in accordance with the voluntarily modus is the social control theory. The social control theory considered to be proper for this modus because crime can be done by every person, but not included to children. The crimes that are committed by the children is caused by child delinquency. Child delinquency is an effect of absent or lack-supervising parents towards their children. The lack of supervision causes children to commit a crime.

\section{c. Social Media or Online}

Nowadays, social media is used by all people, whether adults or children, make any kinds of crime arise through social media, including human trafficking and many kinds of crime that are unknown to the police. One of the modus operandi that is used by the children as the offender of human trafficking is through social media, as it is easy to access and

\footnotetext{
${ }^{18}$ Interview with a child as the offender/child delinquent, Melati (not her real name), $18^{\text {th }}$ March 2019, at 17.00 West Indonesia Time.

${ }^{19}$ Interview with Chief Unit of Women and Children Service, I Maculata Sherly M., on 30 April 2015.

${ }^{20}$ Interview with Yuli Wimudji Lestari, on 30 April 2015.
} 
remained confidential. This modus operandi is often used by the children as the offender since the crime that is committed through social media can rarely be exposed due to the privacy policy of various social media have. The social media that often used by the children as the offender in committing the crime started from getting acquainted with doing the transaction, are Facebook (FB), Instagram (IG), Whatsapp (WA), and Line, as Melati said in the interview. ${ }^{21}$

Those three modus operandi that are committed by children in human trafficking violates the Article 2 paragraph (1) of Human Trafficking Law because that modus fulfil the element of 'giving payment' or 'benefit' from the person that holds control of the victim for exploitation even though the crime was committed under the victim's consent. This finding is by the interview with Immaculata Sherly. M. She stated that "The children who committed human trafficking do not act like how adults do recruitment which is by intimidating someone with the violence to be recruited. But in the cases of children as the offender, the element of exploitation still exist. So eventhough they are children, they still violate the Article 2 paragraph (1) of Human Trafficking Law. Exploitation exist when there is a transaction or payment of the victim to the offender. Here, the children are exploitated the sexuality to be sold to the clients." 22

The interview result with the Chief of Women and Children Service Unit explained that the children inviting a friend violate the rule in the article 2 paragraph (1) of Human Trafficking Law, as it is said that if the 'exploitation' as the element has been fulfilled, then an action can be stated as human trafficking.

\section{The Effort of the National Police to Prevent and Overcome Human Trafficking Committed by Children}

In its formulation, Human Trafficking Law must formulate an act of crime that is by the development purpose or as it is commonly known nowadays as the vision and mission of development implementation. The act of crime must be by the development purpose so that it won't give an impact on unwanted events or going off track from the purpose of crime eradication. ${ }^{23}$ Children are supposed to be protected by society so that they won't commit any crime. Children are entitled to live and growing up is their basic rights that must be protected by the state, government, society, family

\footnotetext{
${ }^{21}$ Interview with Melati.

${ }^{22}$ Interview with Chief of Women and Children Service Unit, Imaculata Sherly M., on 30 April 2015.

${ }^{23}$ Syarif Hassyim Azlzurrahman, "Pembaharuan Kebijakan Pidana Kejahata Perdagangan Orang, Yustisia", Jurnal Hukum Universitas Sebelas Maret, Vol. 3, No. 2, p.3.
} 
and parents. ${ }^{24}$ Children as the offender of human trafficking are one of the highest committed crime by children in Surabaya. With various kinds of modus operandi, the police find it hard to prevent and eradicate this crime. Human trafficking is an organised act of crime that makes the law enforcement to work hard on eradicating it and the children as the offender of human trafficking can be a better person since they are still underage, they still have a long future awaits.

There are two kinds of effort in handling an act of crime which is by prevention and repressive. Preventive effort strives for how to prevent an act of crime to ever occur in the future. The effort is including all sectors of social policy, whether it is internal or external steps. ${ }^{25}$ The repressive effort is all actions that are done by law enforcer after an act of crime is committed. Considering the speciality that children have, the legal proceeding especially, the deprivation of independence, it must be the last attempt (ultimum remedium) if another attempt was failed to be conducted. ${ }^{26}$

\section{Conclusion}

The conclusion on the discussion of the problem, i.e.;

1. Modus Operandi of children in committing human trafficking, especially in Surabaya are:

a. Inviting a Friend

b. Voluntarily

c. Social Media or Online

2. The effort of Police in preventing and eradicating children as the offender of human trafficking are:
a. Preventive
b. Repressive

\footnotetext{
${ }^{24}$ Lurensisus Arliman A., "Partisipasi Masyarakat di dalam Perlindungan Anak yang Berkelanjutan sebagai Bentuk Kesadaran Hukum", PADJADJARAN Jurnal Ilmu Hukum (Journal of Law), Vol. 3, No. 2, (2016), p.16.

${ }^{25}$ Hety Ratna Novitasari dkk, "Analisis Kriminologis Terhadap Pengulangan Tindak Pidana Penyalahgunaan Narkotika Oleh Anak”, Jurnal Poenale, Vol. 3 No. 2, (2015), p 9.

${ }^{26}$ Prima Astari, "Landasan Filosofis Tindaan Kepolisian Terhadap Anak yang Berhadapan dengan Hukum", Arena Hukum, Vol. 8, No. 1, (2015), p8.
} 


\section{A. Buku}

\section{Bibliography}

Ashshofa, Burhan. (2002). Metode Penelitian Hukum. Jakarta: Rineka Cipta Atmasasmita, Romli. (1992). Teori Dan Kapita Selekta Kriminologi. Bandung: Refika Aditama.

Marlina. (2009). Peradilan Pidana Anak di Indonesia Pengembangan Konsep Diversi dan Restroative Justice. Medan: Refika Aditama.

Masruchin, Rubai. (2001). Asas-Asas Hukum Pidana. Malang: UM PRESS dengan Fakultas Hukum Universitas Brawijaya.

Prasetyo, Teguh. (2011). Kriminalisai Dalam Hukum Pidana. Bandung: Nusa Media.

Santoso dan Eva Achjani Zulfa. (2001). Kriminologi. Jakarta: Raja Grafindo Persada.

Sunggono, Bambang. (2005). Metodologi Penelitian Hukum. Jakarta: Raja Grafindo Persada.

\section{B. Journal}

Afan Alfian, "Upaya Perlindungan Hukum Terhadap Tindak Pidana Perdagangan Orang", Fiat Justisia Jurnal Imu Hukum, Vol. 9 No.3, (2017), https://doi.org/10.25041/fiatjustisia.v9no3.603 .

Agung Fernando Satrya, "Analisis Kriminologis Tentang Anak Pelaku Pencurian Dengan Kekerasan Yang Menggunakan Senjata Tajam", Jurnal Poenale, Vol. 5, No. 6, (2017).

Hety Ratna Novitasari dkk, "Analisis Kriminologis Terhadap Pengulangan Tindak Pidana Penyalahgunaan Narkotika Oleh Anak", Jurnal Poenale, Vol. 3 No. 2, (2015).

Hotlarisda Girsang, "Pemberantasan Tindak Pidana Perdagangan Orang Melalui Undang-Undang Pencegahan dan Pemberantasan Tindak Pidana Pencucian Uang", Jurnal Ilmu Hukum, Maret, (2004).

I Gst. Ayu Stefani Ratna Maharani \& Ida Bagus Putra Atmadja, "Sanksi Pidana Terhadap Tindak Pidana Perdagangan Orang (Human Trafficking) Di Indoesia", Jurnal Hukum Universitas Udayana, Vol. 04, No. 03, (2015).

Lurensisus Arliman A., "Partisipasi Masyarakat di dalam Perlindungan Anak yang Berkelanjutan sebagai Bentuk Kesadaran Hukum", PADJADJARAN Jurnal Ilmu Hukum (Journal of Law), Vol. 3, No. 2, (2016), https://doi.org/10.22304/pjih.v3n2.a5 .

Prima Astari, "Landasan Filosofis Tindaan Kepolisian Terhadap Anak yang Berhadapan dengan Hukum", Arena Hukum, Vol. 8, No. 1, (2015), https://doi.org/10.21776/ub.arenahukum.2015.00801.1_ 
C. World Wide Web

Detik.com, 2012, Dua Gadis Belia Dijual Teman Sendiri Seharga Rp 1 Juta (online),http://news.detik.com/surabaya/read/2012/07/16/142250/19663 43/466/dua-gadis-belia-dijual-teman-sendiri-seharga-rp-1-juta, accessed on $16^{\text {th }}$ December, 20.12 West Indonesia Time.

\section{Legislation}

Law Number 39 of 1999 on Human Rights.

Law Number 23 of 2002 on Child Protection.

Law Number 21 of 2007 on Human Trafficking. 
